\title{
Moral calculus and the bomb
}

\section{Targeting civilians, not using atomic weapons, was the moral watershed.}

\section{Kurt Gottfried}

 he moral dilemmas thrown up by science are starkly illustrated by the discovery of nuclear fission. With the impact of science on society certain to increase in the next millennium, what can we learn from the story of nuclear weapons?

Since 1945 there has been constant debate as to whether the killing of nearly 200,000 Japanese civilians with nuclear weapons was morally justified. Given that by that time the creation of nuclear weapons was inevitable, perhaps the greater tragedy is that their birth could have come sooner, and saved far more lives than were extinguished in Hiroshima and Nagasaki.

It was not a foregone conclusion that the atomic bomb would only become available as late as August 1945. My colleagues Hans Bethe and Robert Wilson, the wartime heads of the theoretical and experimental nuclear physics divisions at Los Alamos, believe that a year was lost because the United States failed to build upon ground-breaking work carried out in England.

Early in 1940, Otto Frisch and Rudolf Peierls in Manchester wrote the memo that showed, for the first time, that the critical mass for ${ }^{235} \mathrm{U}$ is astonishingly small, and that large-scale separation of this isotope might be feasible. Leading scientists, who reported to Churchill's War Cabinet, refined these ideas and by the year's end were convinced that a bomb could be built within several years. By contrast, fission research in the United States received paltry government support. Only after repeated entreaties from British physicists did Roosevelt, in October 1941, decide to commit a major effort to the building of the bomb.

So, a good portion of a year - if not actually a whole year - could have been saved. Setting detailed speculations aside, consider the consequences had the bomb been available at various earlier times.

In the Pacific theatre, six months would have made an enormous difference. The systematic fire bombing of the great Japanese cities only began in March 1945, and killed more people in Tokyo alone than were to die in Hiroshima. Okinawa was captured in the spring of 1945 with 20,000 US and 110,000 Japanese military fatalities.

Many believe that the Western Allies would not have used the bomb against Europeans. There is no basis for this speculation. We had no qualms about burning alive some 135,000 civilians in Dresden, even though this beautiful city had no military value and

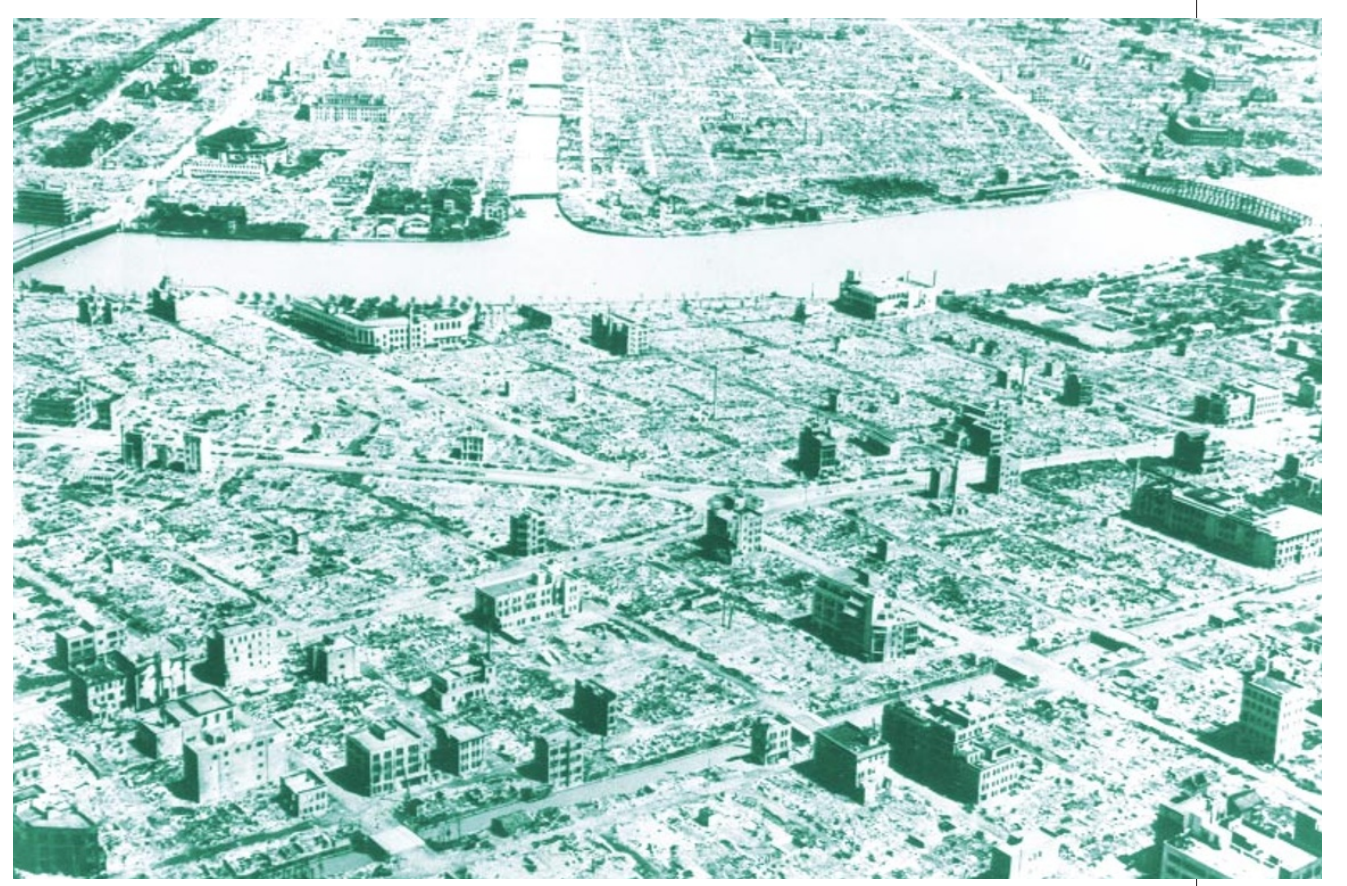

Atomic desolation? No, this was Tokyo in 1945, after saturation bombing with non-nuclear weapons.

was about to fall to the Red Army. Surely the bomb would have been used against the Nazi state, and, if feasible, against Hitler himself. After Stalingrad and the Normandy landings, there were many in the German High Command who knew the war was lost; Hitler could not have survived politically in the face of atomic attack. And repeated attacks would have been possible, because by the end of the war the Manhattan Project could produce one Nagasaki-type plutonium bomb roughly every two weeks.

Had the bomb ended the European war in December 1944 — eight months before it fell on Hiroshima and two months before the Yalta conference that divided up Europe the Soviet army would not yet have held Warsaw or Budapest, and would have still been far from Prague. Tens of millions would not have had to endure 44 years of Soviet

he combination of
new science with
the abandonment of
a profound moral
principle can lead to
dangers that could not
have been imagined

occupation. The lives of an enormous number of soldiers on the Eastern front, and a smaller number on the Western front, would have been saved. A significant portion of the millions who died in Nazi death camps would have survived. Even if the war in Europe had ended in April 1945, instead of in May, the benefits would still have been substantial.

The profound moral divide that was crossed by the great democracies was their considered decision to systematically kill civilians by strategic bombing. Once that became routine, the use of the atomic bomb for the same purpose followed inexorably. The subsequent deployment of grotesque thermonuclear arsenals, that put whole societies at risk, and the adoption of military postures that reduced decision times to less than 30 minutes posed a far graver affront to morality and sanity, and proved to be virtually unavoidable.

The use of the bomb in the Second World War illustrates the obvious in the starkest terms: moral calculus does not lead to unambiguous answers. And the whole history of the nuclear age shows that the combination of new science with the abandonment of a profound moral principle - in this case that civilians should not be military targets can lead to awesome dangers that could not have been imagined at the outset.

Kurt Gottfried is at the Laboratory of Nuclear Studies, Cornell University, Ithaca,

New York 14853-5001, USA 